\title{
Study on the relationship between the main interests of the parties in the development process of Inner Mongolia industrial and mining industry from the perspective of game theory and its reasons
}

\author{
Yang Changbao ${ }^{1}$, Wu Xiuqing ${ }^{2}$ \\ ${ }^{1}$ Inner Mongolia University School of Ethnology and Sociology 010010 \\ ${ }^{2}$ Hohhot Minzu College of Environmental Engineering 010051
}

Keywords: game relationship; industrial and mining development; stakeholder; herdsman

\begin{abstract}
Based on the field investigation in Damo County, Inner Mongolia, this paper interviewed the government departments, industrial and mining enterprises and herdsmen in the survey area to find out the attitudes and opinions of various stakeholders on the industrial and mining development in grassland and pastoral areas as well as the manifestations of specific behaviors. On the basis of this, we use game theory to analyze the relationship between the main interests of all parties and their causes. This is of great significance in exploring the sustainable development of mineral resource-based enterprises in grassland and pastoral areas in Inner Mongolia. It is of great significance to national unity and equality among all ethnic groups, to common prosperity and to the building of a harmonious society.
\end{abstract}

\section{Introduction}

Since the implementation of the strategy for the great development of the western region in our country, the average growth rate of GDP has exceeded 10\% and the GDP growth rate has ranked first in the country for eight consecutive years. In particular, among the 12 provinces and municipalities in the western region, Inner Mongolia recorded the fastest growth and far exceeded the national average. The economic development in Inner Mongolia mainly relies on the investment in fixed assets and the exploitation of natural resources, and the stimulating effect of institutional innovation and technological progress on economic growth is not obvious.

At the same time, the rapid industrial and mining development has brought negative impacts on the ecological environment and aggravated various social conflicts, thus threatening the sustainable development of grassland and pastoral areas, which has aroused widespread concern and heated discussion in academia.

Throughout the past related research, for example, the research in the field of natural science has placed too much emphasis on the technical aspects of resource development and economic development, while neglecting the sustainability of "man and nature", or not focusing on the herdsman and on the discussion of grassland culture. In the field of social science, the analysis mainly focuses on the macro level. Some scholars have made some discussions at the micro level and put the research center on several aspects such as environmental protection, ecological compensation, cultural heritage and sustainable development. However, based on the combination of theory and practice (fieldwork), a comprehensive and systematic analysis of the game relationship between stakeholders, such as local government, industrial and mining development enterprises and herdsmen, is still lagging behind in academic circles.

Therefore, it is necessary for us to focus on the relationship between the main interest groups in the process of industrial and mining development from the perspective of the combination of theory and practice. This not only fills in the gaps in the study under the new situation in the new era, but also provides the industrialized construction in the minority areas Reference and basis. 


\section{Research object}

In 2002, Inner Mongolia Baotou City, Darhan Maoming Union flag (hereinafter, Damo Banner) put forward the "industrial banner, three production promotion" development strategy, industrial development thinking planning flag local economic development. Under the guidance of such policies, in 2004, Barun Mining Co., Ltd. (a wholly-owned subsidiary of Baotou Steel Group and Barrun Corporation below) developed the Baiyunebo West Mine and commandeered an Zhen Chao Lu Ming Sheila Damao GA check 26 herdsmen 92055 acres of pasture.

The research area of Baiyunebo West Mine is one of the main industrial and mining enterprises that promote the economy of Damao Banner. Bayan Obo West Mine is extremely rich in resources. The investigation point involved in this research case is Luca Chala, Sheila, Ming'an Town. Sheila Chacha Lugacha Chailan Chaolu Temple, administered 62 herders, covers a total area of 75.19 hectares, grassland area of 63.91 hectares, the total number of 273 households, $763^{1)}$.

This article uses game theory to carry out the field investigation through the analysis of the mutual interest game relationship among 26 herdsmen, local governments and Barrun companies involved in the industrial and mining development process.

\section{Theoretical perspective}

Game theory, also known as game theory, is a theory that studies the conflicts and cooperation among rational decision makers. It studies how decision-makers and their balances in the direct interaction of decision-making actors. Academically, there is no uniform conclusion about the exact definition of game theory.

The tripartite relationship in the development of industrial and mining grassland and pastoral areas, that is, the relationship between the herdsmen, local governments and industrial and mining enterprises can be regarded as a typical game activity.

\section{Grassland pastoral areas of industrial and mining development activities of all stakeholders}

First, local government, as a participant and implementer of mineral resource management, on the one hand, local government, on behalf of the state, manages mineral resources in accordance with the law, regulates the order of development of mineral resources and enjoys the benefits of mining development. On the other hand, in order to maximize its own interests, and strive to get more benefits and policies in the process of dealing with the national administrative rights. The benefits of local governments include access to land transfer income, the pursuit of performance, official rent-seeking, follow-up management and other benefits.

Second, industrial and mining enterprises, the cost of enterprises in the land acquisition process depends on the level of land compensation fees. The purpose of enterprises in the process of land requisition is to pursue maximization of profit and minimize investment. Specifically, the first is to minimize the costs of various compensation fees such as land transfer fees. The second is to avoid negotiating prices on a household-by-household basis and seek the government's enforcement.

Third, pastoralists, since land acquisition is generally compulsory, the standard of compensation for land expropriation is negotiated between the government and enterprises. Therefore, the rights of barbarians are deprived of their rights from a legal point of view. The government adopts price controls to lower the prices of pasture land to maximize their own interests. As a rational "economic man," pastoralists are bound to increase their incomes and resist expropriation through other channels.

\section{The main stakeholder analysis of the game}

This study uses the author's field investigation data from Damo Banner of Baotou City in Inner Mongolia for several times since 2012 to analyze the game relationship between local government, industrial and mining enterprises and pastoralists in the process of industrial and mining development in grassland and pasture in Inner Mongolia. This game relationship can be analyzed 
from the following two aspects.

(1) The game analysis between the local government and the industrial and mining enterprises.

In the example of the survey area, local governments and development enterprises have become common interests. The role of industrial and mining enterprises is more like a stealth behind the scenes, he will point out the total cost to the government, and then the government came forward to the expropriated herdsman, the recovery of land use rights, define the compensation standards, limit the expropriation of grassland, and through the public power intervened in the land acquisition disputes, thus locking the civil legal rights of herdsmen (such as the right to information, the right to compensation, relief, etc.) to maximize the benefits and costs. However, without the consent of the land-expropriated pastoralists, the government will unilaterally reclaim its land-use rights as the owner of the state land and transfer it to the industrial and mining enterprises at a high price to obtain high land transfer fees. Taxes, its outstanding achievements, benefits are also good. This result is indeed a "win-win" option for the government and industrial and mining enterprises.

(2) The game analysis between local governments, industrial and mining enterprises and landless pastoralists.

Herdsmen play a role in the process of industrial and mining development in pastoral areas of Inner Mongolia. In the process of public welfare land acquisition and development, they cannot confront the government's mandatory demolition. It is very difficult to apply for administrative remedies. In private-owned land acquisition activities, the enforcement of government applications, the corresponding reduction in the right to appeal, the overall procedural rights asymmetry, into a "lost law" and helpless situation.

\section{Mining industry development activities in the game analysis of the root causes}

In the case of this study, the root causes of the above game relationship can be analyzed from the following aspects.

First, it is in the deep institutional conflicts that make up the old stage of history. It should be said that the land acquisition in contemporary China is an inevitable phenomenon of the rapid development of cities after the reform and opening up, with prominent historical reasons and realistic reasons. From the planned economic system to the market economy, the large-scale land acquisition will inevitably lead to a huge conflict of interests among multiple subjects, resulting in a variety of acts "anomie" and disputes. Under the conditions of a planned economy, the interests are often monadic, that is, individual interests and national interests and social interests are highly consistent. Under the conditions of a market economy, the interests of all classes, classes and individuals are diversified and the mechanism for resolving conflicts of interest is correspondingly diversified.

Second, the absence of real rights protection system, the lack of coordination of norms of land use rights. The Constitution of our country stipulates: "The land in the cities belongs to the state, and the land in the rural areas and the suburbs of cities belongs to the collective except those which are legally required to belong to the state" (Article 10); "The state may, in the public interest, Land shall be requisitioned or requisitioned and compensated in accordance with the law " (Article 10, paragraph 3). As a result of the coexistence of two kinds of rights of land ownership and tenure in one article at the same time, the land ownership owned by the requisitioned herdsmen has actually become a vulnerable right that can easily be violated by state power. That is, even if an agreement cannot be reached with the requisitioned pastoralists, if the industrial and mining enterprises get the land use right through the transfer of the state-owned land use right or the transfer of the secondary land market, they can carry out the development activities "legally" regardless of the rights of pastoralists.

Third, grassland compensation fees are too low. According to Article 25 of the Inner Mongolia Autonomous Region Grassland Management Regulations (adopted at the 2nd meeting of the 6th People's Congress of Inner Mongolia Autonomous Region on June 7, 1984, revised in 2004), "In order to meet the needs of the public interest of the state and the autonomous region, Grassland compensation fees, resettlement subsidies and attachments compensation fees shall be paid 
according to law or expropriation of grasslands. Grassland compensation fees shall be paid in accordance with the sum of the average rearing value of livestock and the value of annual economic plant in the previous five years of requisition or requisition Times; the resettlement subsidy shall be paid according to ten to fifteen times of the sum of the average rearing value of livestock per mu acquired or expropriated for the past five years and the annual value of economic plants; the compensation for attachments shall be paid in accordance with the actual losses. Pastoral grassland collection is from 2005 onwards. The Inner Mongolia Autonomous Region Grassland Management Regulations revised in 2004 should be applied to this development activity. Eight times the grassland compensation fees paid by local governments to local herdsmen do not match 10 times of the above provisions. The actual payment of 5 times the resettlement subsidy and the above provisions of 10-15 times the difference. This is one of the main reasons why pastoralists have long been dissatisfied with the government's development activities.

Fourth, the "non-economic losses" of landless herdsmen are not considered. The relevant provisions of the state did not specifically mention the "herdsman" this special status. In general, "pastoralists" are part of "peasants" and the relevant provisions can only be treated in the same way as "peasants." However, the "herdsman" status in Inner Mongolia is different from the "peasant" status in the Han nationality. Herdsman's living environment and production and lifestyle decision herdsmen's personality traits and nature. The unplanned and regular herdsmen's management of money has led herdsmen to exhaust the compensation within a short period of time. After ten years, pastoralists have already lost all their savings and have lost their foundation for living. Such land-expropriation models, which are only considered in terms of money, have brought great difficulties to the sustainable livelihood of pastoralists.

\section{Conclusion}

Through field investigation, this study interviewed the government departments, industrial and mining enterprises and herdsmen in the survey area to understand the attitudes and opinions of various stakeholders on the development of industrial and mining grassland and pastoral areas as well as the manifestations of specific behaviors. On the basis of this, based on the use of game theory, it is necessary to organize the survey data and data and summarize the respective interests of the tripartite subjects, and analyze the game relationship between them and the causes of their formation. This is the right way to explore the sustainable development of mineral resource-based enterprises in pastoral areas of Inner Mongolia, and it is of great importance to the government and relevant departments to put forward countermeasures and suggestions on how to solve the problems. At the same time, it is very important for the ethnic solidarity and the ethnic equality, common prosperity and the building of a harmonious society Meaning.

\section{Acknowledgements}

This article is part of the research results of the western project of National Social Science Fund Project "Study on the Interests in the Process of Industrial and Mining Development in Inner Mongolia Grassland and Pasture Based on Game Theory" (16XMZ077, Principal: Yang Changbao).

\section{References}

[1]. Uday Taoke sets (2015) "New pastoral area construction and animal husbandry industrialization development - Take Inner Mongolia Autonomous Region as an example" People's Publishing House;

[2]. Chana (2007) "Study on the Industrialization Growth Pattern of Inner Mongolia Muye Banner County Based on Circular Economy" Inner Mongolia University Press;

[3]. Chang Yaping (2008) "Research on Sustainable Development of County Economy in Resource-Rich Areas - A Case Study of Wushen Banner in Inner Mongolia" China Economic Publishing House; 
[4]. Zhang Fuming (2010) "mineral resources development of ecological environment compensation mechanism" Economic Science Press;

[5]. Qi Yabin et al. (2009) Research on Compensation Mechanism for Development of Mineral Resources China Earth Publishing House;

[6]. Song Lei (2012) "Research on Ecological Compensation for Exploitation of Mineral Resources" China Economic Publishing House;

[7]. Wang Zhenyu et al. (2012) Study on Compensation Rates for Soil and Water Loss in Exploitation of Mineral Resources - A Case Study of Liaoning Province; Economic Science Publishing;

[8]. Ren Jianxiong (2010) "Path Innovation and Coordination Mechanism for Exploitation and Utilization of Regional Mineral Resources" Zhejiang University Press;

[9]. Darling too (2010) "pastoral and market - herdsman economics" social science literature publishing house. 